\title{
ORGANIZATIONAL CULTURE VERSUS NATIONAL CULTURE: A CROSS CULTURAL PERSPECTIVE ON THE INDIVIDUAL ORGANIZATIONAL LEARNING CAPABILITY
}

\author{
Naniek Setijadi a ${ }^{a}$ Roy Pratikno ${ }^{b}$ \\ ab Universitas Pelita Harapan, Jakarta, Indonesia \\ Corresponding email: naniek.setijadi@uph.edu
}

\begin{abstract}
Organizations are culture-bound (Hofstede, 2001). A proponent of the organizational culture would argue that organizational culture has profound impact on the performance and sustainability to the organization; yet, the supporters of national culture believe that national cultures can play a role in distracting or strengthening the organizational culture to shape the organization and boost the performance of the organization. Some scholars pose questions whether national cultures constrain organizational culture (Gerhart, 2008). However, Hofstede (2001) argued that to achieve great performance an organization should pay attention to national culture. Each proponent has compelling arguments as to why their side has much profound impact compare to the other side. Organizational learning is primarily about individuals learning within their organization. Human learning in an organizational context is strongly influenced by the organization, having consequences to the organization, which results at the organizational level can only be inferred by observing the learning process of everyone within it. This study aimed to investigate the organizational learning capability among employee, as organizational culture intertwined with different national cultures. Data are collected by in-depth interviewing Expatriates and local workforce in a multinational company and in one higher education institution in Jakarta; exploring individual perceived organizational learning capability: experimentation, risk taking, interaction with the external environment, dialog, and participative decision making.
\end{abstract}

Keywords: Cross-culture, Individual Organizational Learning Capability; National Culture; Organizational Culture.

\section{Introduction}

The importance of individual learning for organizational learning is obvious since all organizations are composed of individuals; however, it is also subtle because organizations can learn independently of any specific individual but not independent of all individuals (Kim, 1993). Human learning in an organizational context is strongly influenced by the organization, having consequences to the organization, which results at the organizational level can only be inferred by observing the learning process of everyone within it (Senge, 1990;Senge, et al., 1999).

According to Peter Senge, learning organizations are: “...organizations where people continually expand their capacity to create the results they truly desire, where new and expansive patterns of thinking are nurtured, where collective aspiration is set free, and where people are continually learning to see the whole together."

Organizational learning is primarily about individuals learning within their organization. Marsick and Watkins (2003), as cited in Tseng and McLean (2008), pointed out that organizations often expect learning and knowledge creation to take place continuously for individuals and that they will share what they know in ways that promote learning in groups and throughout the organization. And thus, organizational learning is particularly significant 
in today's workplace where employees may feel that sharing knowledge could be detrimental to their success.

\section{Learning Organization vs Organizational Learning}

The idea of a learning organization has become increasingly prominent over the last two decades, since Peter Senge introduced the conceptual underpinnings of the work of building learning organization. It was in this context that Peter Senge (1990) began to explore 'The art and practice of the learning organization'. Learning organizations are organizations where people continually expand their capacity to create the results they truly desire, where new and expansive patterns of thinking are nurtured, where collective aspiration is set free, and where people are continually learning to see the whole together (Senge, 1990, p. 3). Thus, the essence of "the learning organization" is a great team, which usually starts as a group of individuals who, over time, enhance their capacity to create what they truly desire to create (Senge et al., 1995). It could be argued that the notion of the learning organization provides managers and others with a picture of how things could be within an organization.

Meanwhile, Weick\& Ashford (2001, p.727) argued: "Organizational learning is primarily about individual learning within their organizations (about themselves and their performance or about how the collective does or should operate) and interacting and competing with others to get their learnings "heard" within organization." As people start to see and experience the world differently, new beliefs and assumptions begin to form which enables further development of skills and capabilities (Senge et al., 1985).

Literature on organizational learning has concentrated on the detached collection and analysis of the processes involved in individual learning inside organizations. However, both the learning organization and organizational learning are similar in that they both involve learning. Whether being the process of learning or the actual institutionalizing of learning, it has become popular in organizations today. The learning organization is classified as "organizational learning", that is the 'activity and the process by which organizations eventually reach the ideal of a learning organization' (Smith, 2001).

The learning organization and organizational learning are slightly different in a way that the learning organization is the process to change and organizational learning is having the process and strategies and implementing change throughout an organization. Simply put, one is the plan, the other is the action. All organizations learn, whether they consciously choose to or not, it is fundamental for their sustained existence; and they learn via their individual member or workforce (Kim, 1993; Tseng \& McLean, 2008).

Learning is a constituent process of human resource development and organizational change. Any organization that ignores change does so at its own peril. The field of organizational change is far from mature in understanding the dynamics and effects of time, process, discontinuity, and context. Particularly, in a complex, dynamic, and internationally conscious world, a search for general patterns of change requires even more focus on temporal and spatial context. Generalizations are hard to sustain over time, and they are even tougher to uphold across international, institutional, and cultural borders. This study will contribute to the understanding of the organizational learning capability among employees (locals and expats) having different cultural backgrounds; by analyzing the processes involved in individual learning inside organizations based in Jakarta.

The relevance of a cross cultural perspective in understanding organizational learning is because organizational culture intertwined with different national cultures; there is no doubt that the two kinds of culture both exert powerful influences on people. Culture consists of "learned systems of meaning, communicated by means of natural language and other symbol systems, having representational, directive (task) and affective (socio-emotional) function, 
and capable of creating cultural entities and particular senses of reality" (D'Andrade, 1984, p.116, cited in Weick\& Ashford, 2001, p.707).

\section{Theoretical Background}

Hofstede (1980, p.71) argued that the "nationality of respondents" explained cultural values of individuals in different countries "highly significantly." Gerhart (2009), citing in Hofstede, pointed out that there is an important vein of academic work that largely assumes that country differences, particularly in national culture, are so important. His work, the "nationality of respondents", explained cultural values of individuals in different countries "highly significantly." Johns (2006, p.396) states explicitly that "national culture constrains variation in organizational cultures'. His argument relies significantly on empirical work by Hofstede (1980, 2001).

Hofstede (1993), in his research, found that cultural characteristics such as language, belief, values, religion, and social organization are generally assumed to be the reasons for different action within each culture. According to Hofstede, culture is a complex network of norms, values, assumptions, behaviors, and beliefs that characterize certain groups, and hence an action more desirable or approved than any other action.

\section{Revisiting Cultural Approach to Organization - A Brief Overview}

An organization's culture can be seen as its members' collective mental model, and that is the reason why we cannot change an organization without investigating its cultural assumptions (Schein, 1992, 1996). In Edgar Schein's model, cultural assumptions are deeply influenced by beliefs held by founders and leaders, carrying for years after the founders themselves have ceased to run the company (Schein, 1992, 1996; Senge et al., 1996). Usually successful organizations have a well-defined and widely used practice organizational culture throughout the organization. "Capacity of an organization to learn how to do what it does, where what it learns is possessed not only by individual members of the organization but by the aggregate itself" (Cook \&Yanow, 1993, p.378, cited in Weick\& Ashford, 2001, p.707).

Clifford Geertz (1973, p.5) said: "Humans are animals suspended in webs of significance that they themselves have spun. Thus, in an organization, it doesn't have a culture; it is culture a unique system of shared meanings." Applying Geertz' cultural insights to organizational life, Pacanowsky (1983) considers culture as more than a single variable in organization. He says that if culture consists of webs of meaning that people have spun, and if spun webs imply the act of spinning, "then we need to concern ourselves not only with the structures of cultural webs, but with the process of their spinning as well" (Griffin et al., 2015). For Pacanowsky, culture is not something an organization has; a culture is something an organization is. He notes that job performance may play only a minor role in the enactment of corporate culture, in this case, employees' performance are actions by which members constitute and reveal their culture to themselves and to others (Griffin, 2015, p.245).

\section{Individual Learning and National Culture}

"Human learning in the context of an organization is very much influenced by the organization, has consequences for the organization, and produces phenomena at the organizational level that go beyond anything we could infer simply by observing learning processes in isolated individuals" (Symson, 1991, p.126, cited in Weick\& Ashford, 2001, p.708). Individual learning is primarily a controlled, mindful activity that is supplemented by tacit knowledge acquisition and operant conditioning. Thus, the key learning dynamics within individual learning is important to be elaborated.

Although considerable individual learning is primarily mindful, Wagner \& Stern (1985) argued that there is evidence that knowledge is also picked up tacitly, as a by-product of 
experience. Tacit or implicit learning plays an important role in the development of procedural knowledge of how complex, real-world systems function (Cohen \&Bacdayan, 1994; Senge\&Sterman, 1992), and in the development of skills, habits, and routines (Squire, Knowlton, \&Musen, 1993). This suggests that learning involves both a situational and selfunderstanding, which is associated with adaptability i.e.: the need to maintain adequate information about the environment, the need to maintain adequate internal conditions necessary to responding, and the need to maintain flexibility (Weick\& Ashford, 2001, p.711).

As such, individuals learning about their own performance or that of their organization are often dialectic between the desire for accurate information and the desire to defend the ego(Weick \& Ashford, 2001). However, to understand the perception of learning organization from the workforce's point of view, we should consider the factor of individual's perception of it as influenced by each individual national culture and identity. Both social identity and personal identity dimensions influence our everyday behaviors in a generalized and particularized manner (Ting-Toomey, 2009, p.493). As cited from Setijadi (2012), Mead (1934) and Schlengker (1980) argued that through interactions with others, people learn how to view themselves and the world. To interact effectively with others, people must learn to place themselves in the positions of others and try to see things from their perspective. That is how people learn about themselves and the world.

National culture is defined as the set of norms, behaviors, beliefs and customs that exist within the population of a sovereign nation; it has six dimensions: power distance, collectivism, individualism, masculinity, and uncertainty avoidance (Hofstede, Hofstede \&Minkov, 2010). The research of Geert Hofstede has shown that cultural differences between nations are especially found on the deepest level; i.e. on the level of values. In comparison, cultural differences among organizations located within the same national culture arena are especially identified on the level of practices. For example, a company may be encouraging and rewarding risk-taking in a country where people are generally risk-averse. Practices are more tangible than values, which also allows for a more precise and specific definition (Waisfisz., n.d.).

\section{The Five Dimensions of Organizational Learning Capability}

Chiva, Alegre and Lapiedra (2011), in their research, have grouped the organizational learning capability scale consisting of 14 items into five dimensions: 1) experimentation; 2) risk taking; 3) interaction with the external environment; 4) dialogue, and 5) participative decision making. They proposed measurement scale for organizational learning capability to unveil which organizational learning issues are strong and which are weak. The five underlying dimensions sum up the facilitating factors for organizational learning proposed by Chiva (2004). Those scales were developed based on a single perspective or literature, mainly the learning organization literature of Senge (1990).

We consider those five dimensions as the most underlined facilitating factors as it suggests factors that facilitate the existence of learning. In "experimentation", factors such as support for new ideas, continuous training or workers that want to learn and improve are included. In "dialogue", factors of communication, diversity, teamwork, or collaboration are considered. While "participative decision making" incorporate delegation, flexible organizational structure, or knowledge of the organization.

The idea of using these five dimensions and applying them to the individual context is to explore whether the assumed learning organization is also perceived as the same by employees who have different cultural backgrounds, since they are foreigners (Expats) and local Indonesian, and to see what influenced those perceptions. 


\section{Methodology}

This study mainly explored the relationship between organizational culture and national culture in the practice of individual's perceived organizational learning capability, using the conceptual model of organizational learning capability (OLC) of Chiva et al. (2004).

The research incorporated in-depth interviews with five informants (three Expatriates and two local workforces), whose names are kept anonymous, from one multinational company and one tertiary education institution, both located in Jakarta; to explore individual's perceived five dimensions of organizational learning capability, i.e.: experimentation, risk taking, interaction with the external environment, dialog, and participative decision making.

The institutions under study were chosen with the consideration that the multinational company has a business orientation, while the educational institution is an organization that is nonprofit-oriented. This is interesting to explore further with the assumption that each organization has a different organizational culture.

\section{Results \& Discussion}

\section{Individual Perceived Organizational Learning Capability}

Emerging from the data, from the very beginning of the interviews, we found that most of our informants spoke very freely about how they felt when asked about their perception on the factors that facilitate learning in their organization. From the interviews with them, we found that there is a slight difference in findings on educational institution and business institution. Nevertheless, all informants from both institutions expressed that in one of the factors that facilitate learning organization, particularly, participative decision-making process, is mostly a top-down one. Even if they are being involved, only a little of their opinion or arguments are considered. This perception is felt particularly by employees who are not in management or leader position.

\section{Business Institution}

Overall results show that employees, expats and locals, male and female, in this business institution have more understanding and tolerance in incorporating all five factors of the organizational learning process. They feel that the organizational or corporate culture is well defined and well socialized by the institution to the entire organization. Particularly, being a multinational company, their organizational culture is strategically established and practiced globally. The five dimensions that facilitate learning in organization are believed to be well socialized and practiced to the entire organization staffs (expats and locals) regardless of their genders.

Still, however, there are feelings or perceptions of local employees that, in many case, the decision-making process is a top-down direction and less involving the locals' opinion or arguments. Working in the multinational company, the expat leaders believe that they know better of the best practice in the company, which has been practiced globally as well, and thus not necessarily or less involving local staffs in decision making process. This portrays the influence of high power distance among local and expat staffs, which can be a hurdle for perceiving or practicing the organizational learning process.

\section{Educational Institution}

Our study found that among academics in the educational institution under study, they tend to adapt to Indonesian national culture as the host culture, rather than to organizational culture. In practice, they tend to adapt to the situation and local wisdom where they are in 
with the understanding that both expats and local employees alike understand the same organizational culture.

There is a perception of one of our expatriate ( $\mathrm{P}$, American) informants, which states that as an expatriate he is often excluded from decision making process or even in all the five factors that facilitate learning, he does not feel those work for him. Worst case is, he even felt that, in many cases, his existence is kind of being "neglected" in the faculty environment. It is due to language barrier as well as national culture issues with some of the local peers and leaderships. Thus, he is not a team player nor involved in any decision making. He pointed out the reason as: "If you're an international... an expat, you have an additional hurdle of trying to change ideas that are not yet seen by the (local) leadership because they failed to understand the value of it". His statement represents a descriptive evaluation on stereotyping based more strongly on culturally determined standards. Stereotype, as argued by Hofstede (2001, p. 17), always reflects the mind-sets of those judging and sometimes also something real about those being judged.

Other expat informant ( $\mathrm{T}$, Australian) of the same institution perceived otherwise. From the interview with him, it can be concluded that he perceived that all those five factors are wellapplied to him, regardless of his position in management. Although, participative decision making and teamwork are encouraged in his faculty, however, he said that, in many cases, the decision-making in his institution is mostly by Top Management (Rectorate/President), and people will have to just follow and work on it. However, when it is about teaching learning activities, he feels that experimentation dimension is strongly encouraged, in a way to improve the quality of the learning achievement of the students. In this case, his control includes time emphasis, attention into details, and goal pressure. Having leadership position in the faculty, he supports new ideas and encourages continuous learning of his staffs; and this is also supported by his faculty Chair, who is a local (a female Indonesian).

\section{Conclusion}

Culture is learned within a society, and it affects the basic values in people's everyday lives. In questioning how national and organizational cultures relate and which of them is stronger, we found a cultural relativism among our informants. The results of our research show that the two kinds of culture both exert powerful influence on people's organizational learning capabilities. We found more agreement across informants from different nationalities that some employees facing actual conflicts between the two are likely to respond in ways typical of their national culture, not their organizational one. Other employees may respond to this "internal" conflict by adapting themselves to the organizational culture, or else, being ignorant to it and just do their own ways.

Regarding the low-high power distance in the work situation that facilitates individual organizational learning capability:

o in business institution: top managers involved in a strategy; power of superiors depends on position and relationship; preference for tasks with calculated risks, and requiring problem solving.

$\circ$ in educational institution: top managers involved in operations; power of superiors depends on control of uncertainties; preference for tasks with sure outcomes, no risks, and following instructions.

Individual's evaluation or judgmental value depends more strongly on their own culturally determined standards. Stereotyping, which reflect the mind-sets of those judging, may hurdle the individual's organizational learning capability. The influence of one's own cultural 


\section{Asia Pacific Journal of Advanced Business and Social Studies \\ ISBN (eBook): 9780994365675 | ISSN : 2205-6033 \\ Year: 2017, Volume: 3, Issue: 2}

environment is clearly recognizable. Their experiences represent the material on which their thinking and is based (Hofstede, 2001: 378).

Gender difference is not perceived as a constraint or a cause for power distance in all dimensions that facilitate individual organizational learning capabilities.

It is in the institutional best effort and interest to assess their organizational/corporate culture, yet it is also important for all the workforces to adapt their national culture, in this case their identity as reflected in their personality and character, to be aligned with the corporate/organizational culture where they work in. This may require some compromising between cultures.

Last but not least, it also needs some ethical sensitivity of both employees and organization to incorporate ethical practice during the learning process. 


\section{References}

i. Chiva, R., 2004. The Facilitating Factors for Organizational Learning in the Ceramic Sector. Human Resource Development International, 7(2), pp. 233-249.

ii. $\quad$ Chiva, R., Alegre, J. \& Lapiedra, R., 2007. Measuring Organisational Learning Capability among the Workforce. International Journal of Mapower, pp. 224-242.

iii. Cohen, M. \& Bacdayan, P., 1994. Organizational routines are stored as procedural memory: Evidence from a laboratory. Organization Science, Volume 5, pp. 554-568.

iv. G Hofstede, 1993. Cultural Constraints in Management Theories. Academy of Management Executive, Volume 7, pp. 81-94.

v. Geertz \& Clifford., 1973. Thick Description: Toward an Interpretive Theory of Culture, in "The Interpretation of Cultures. New York: Basic Books.

vi. Gerhart, B., 2009. Does National Culture Constrain Organizational Culture and Human Resource Strategy? The Role of Individual Mechanisms and Implications for Employee Selection. Research in Personnel and Human Resources Management. s.l.:Emerald Group Publishing Limited..

vii. Griffin, E., Ledbetter, A. \& Sparks, G., 2015. A First Look At Communication Theory. 9th ed. New York: McGraw-Hill Education.

viii. Hofstede, G., 2001. Culture's Consequences: Comparing values, behaviours, institutions, and organizations across nations. 2nd ed. Thousand Oaks, CA: Sage Publications.

ix. Hofstede, G., Hofstede, G. \& Minkov, M., 2010. Cultures and Organizations: Software of the Mind. Revised and Expanded. 3rd ed. New York: Mc-Graw Hill.

x. Johns, G., 2006. he Essential Impact of Context on Organizational Behavior. Academy of Management Review, 31(2), pp. 386-408.

xi. Kim, D., 1993. The Link between Individual and Organizational Learning. Sloan Management Review, pp. 37-50.

xii. $\quad$ Marsick, V. \& Watkins, K., 2003. Demonstrating the value of an organization's learning culture: The dimensions of the learning organization questionnaire. Advances in Developing Human Resources, 5(2), pp. 132-151.

xiii. Pacanowsky, M. \& O’Donnel-Trujillo, N., n.d. Organizational Communication as Cultural performance. Communication Monographs, Volume 50, p. 129.

xiv. Schein, E., 1996. Culture: The Missing Concept in Organization Studies. Administrative Science Quarterly, 41 (2), 40th Anniversary Issue (June, 1996), 229-240. [Online] Available http://www.jstor.org/stable/2393715?seq=1\&cid=pdfreference\#references tab contents

xv. $\quad$ Senge, P. et al, 1996. The Fifth Discipline Field Book. London: Nicholas Brealey Publishing.

xvi. $\quad$ Senge, P., 1990. The Fifth Discipline. The art and practice of the learning organization, London: Random House..

xvii. Senge, P. et al., 1999. The Dance of Change: The Challenges of Sustaining Momentum in Learning Organizations. New York: Doubleday/Currency.

xviii. Senge, P. \& Sterman, J., 1992. Systems thinking and organizational learning: Acting locally and thinking globally in the organization of the future. In: T. K. \&. M. Useem, ed. Transforming organizations. New York: Oxford University Press, pp. 353-371.

xix. Setijadi, N., 2012. Perceived Self and Identity Negotiation of the Cosplayers: An Analysis of the Identity Change Processes of the Cosplayer Fans. Humanities and Social Sciences Review, pp. 107-116. 
xx. Smith, M., 2001. [Online] Available at: http://www.infed.org/biblio/learning-organization.htm [Accessed 1 November 2008].

xxi. Squire, L., Knowlton, B. \& Musen, G., 1993. The structure and organization of memory. Annual Review of Psychology, Volume 44, pp. 453-495.

xxii. Ting-Toomey, S., 2009. Identity Theories in Little John \& Foss, Encyclopedia of Communication Theory. Thousand Oaks, CA: Sage Publications.

xxiii. $\quad$ Tseng, C. \& McLean, G., 2008. The Relationship between Organizational Learning Practices and the Learning Organization. [Online] Available at: http://files.eric.ed.gov/fulltext/ED501670.pdf

xxiv. Wagner, R. \& Sternberg, R., 1985. Practical Intelligence in Real World Pursuits, the Role of Tacit Knowledge. Journal of Personality and Social Psychology, Volume 49, pp. 436-458.

xxv. Waisfisz., $\quad$ B., $\quad$ n.d. An organizational cultural perspective. [Online] Available https://geerthofstede.com/tl files/art\%20organisational\%20culture\%2operspective.pdf

xxvi. Weick, K. \& Ashford, S., 2001. Learning in Organizations. In: F. Jablin \& L. Putnam, eds. The New Handbook of Organizational Communication: Advances in Theory, Research, and Methods. Thousand Oaks, CA: Sage Publications, pp. 704-721. 